\title{
Use of scanning electron microscopy and high-performance liquid chromatography to assess the ability of microorganisms to bind aflatoxin $M_{1}$ in Minas Frescal cheese
}

\author{
Bruna Leonel GONÇALVES ${ }^{1}$, Romulo Dutra ULIANA', Sarah Hwa LEE¹, Carolina Fernanda COPPA ${ }^{1}$,
} Carlos Augusto Fernandes de OLIVEIRA ${ }^{1}$ (D), Eliana Setsuko KAMIMURA ${ }^{1}$, Carlos Humberto CORASSIN ${ }^{1 *}$

\begin{abstract}
The aim of this study was to evaluate the capacity of two strains of lactic acid bacteria (LAB), Lactobacillus rhamnosus and Lactococcus lactis, and a yeast strain, Saccharomyces cerevisiae, inactivated by heat $\left(121^{\circ} \mathrm{C}, 10 \mathrm{~min}\right)$, from binding to aflatoxin $M_{1}\left(A F M_{1}\right)$, as well as the interaction between these microorganisms, aflatoxin $M_{1}$ and the Minas Frescal cheese matrix after 2 and 30 days of storage. The ability of LABs and S. cerevisiae to bind AFM to Minas Frescal cheese was evaluated by high performance liquid chromatography (HPLC) composed of a fluorescence detector. The interaction between these microorganisms and $\mathrm{AFM}_{1}$ was evaluated using a scanning electron microscope composed of a backscattered electron detector with a voltage of $15 \mathrm{kV}$ and magnifications of $1000 \times, 5000 \times$ and $8000 \times$. The use of microorganisms as a biological method is efficient in reducing AFM in Minas Frescal cheese and does not affect the microbiological parameters. AFM reduction varied according to the microorganism used in the treatments. S cerevisiae showed greater capacity to bind AFM over time, compared to LABs. Scanning electron microscopy was especially useful, confirming that lactic acid bacteria and S. cerevisae were able to bind AFM particles in Minas Frescal cheese.
\end{abstract}

Keywords: S. cerevisiae; lactic acid bacteria; mycotoxins; dairy; aflatoxins.

Practical Application: One of the main objectives of the food industry is to avoid contamination by mycotoxins in processes and products. Methods that can verify the effectiveness of decontamination of aflatoxin $M_{1}$ by microbial action are extremely important.

\section{Introduction}

Aflatoxins are secondary metabolites produced by toxigenic fungal species belonging to the Aspergillus genus, mainly $A$. flavus, A. parasiticus e A. nomius. Aflatoxin $\mathrm{B}_{1}\left(\mathrm{AFB}_{1}\right)$ is toxic, carcinogenic, teratogenic and/or mutagenic easily found as a contaminant in animal diet. Feeding dairy cows with fodder or any contaminated ingredient of the animal diet with $\mathrm{AFB}_{1}$ results in the metabolic conversion of $\mathrm{AFB}_{1}$ to aflatoxin $\mathrm{M}_{1}\left(\mathrm{AFM}_{1}\right)$, which is excreted in milk, in addition, it will be presented in the final product due to heat treatment resistance (Öztürk Yilmaz \& Altinci, 2019; Hajmohammadi et al., 2020; Min et al., 2020; Park et al., 2020).

Milk and dairy products are frequently consumed by a portion of the population considered vulnerable, children and the elderly (Park et al., 2019; Ahmadi, 2020). Minas Frescal cheese is a typical Brazilian product, it is one of the most highly consumed lactic products, showing wide national market acceptance. This is a fresh soft white cheese, slightly salted, with a slight lactic acid taste. It is produced by the enzymatic coagulation of pasteurized milk with rennet or other appropriate coagulating enzymes (Prezzi et al., 2020).

The negative impact of aflatoxins on health and economy has led to investigations of strategies to prevent their formation in food, as well as to eliminate, inactivate or reduce the availability of these toxins in contaminated products (Gonçalves et al., 2015a;
Bodbodak et al., 2018; Cagri-Mehmetoglu, 2018; Assaf et al., 2019; Martey et al., 2020).

In this context, biological methods of reducing mycotoxins arose, which come from the action of microorganisms, such as bacteria, yeast and others. Biological availability reduction methods have been extensively studied as they are efficient, cost-effective, and in many cases, already used in food production such as lactic acid bacteria and S. cerevisiae (Assaf et al., 2019; Barukčić et al., 2018; Cagri-Mehmetoglu, 2018; Campagnollo et al., 2020; Corassin et al., 2013; Gonçalves et al., 2015b, 2020; Ma et al., 2017).

Scanning electron microscopy is a versatile and useful technique, with a wide variety of commercial, industrial and research applications. It involves a finely collimated electron beam that scans the surface of the sample being analyzed. The beam is focused on a small probe that scans the surface of the sample. The interactions of the beam with the material result in the emission of electrons and photons when electrons penetrate the surface, and emitted particles are collected with the appropriate detector to provide surface information. The end product of the electron beam collision with the sample surface is an image (Lee et al., 2019).

In the present study, scanning electron microscopy was used to characterize the surface of biological additives and aflatoxin 
$M_{1}$ separately and together, depending on the treatment, in order to observe surface changes when aflatoxin is adsorbed. Additionally, the microstructure of cheese samples was evaluated.

\section{Materials and methods}

\subsection{Material}

Whole milk, probiotic culture composed of Lactobacillus rhamnosus (LRB, SACCO, Cadorago, Italy) and Lactococcus lactis (MWO 040, SACCO, Cadorago, Italy), a Saccharomyces cerevisiae strain (Fermentis K-97, SafAle, Belgium), liquid rennet (chymosin and bovine pepsin, Ha-La, Christian-Hansen ${ }^{\circledR}$, Brazil) and Aflatoxin $\mathrm{M}_{1}$ standard (Sigma Aldrich ${ }^{\circledast}$ ), were used in this study.

\subsection{Manufacture of Minas Frescal cheese}

The Minas Frescal cheese were manufactured according to Fernandes et al. (2012). The cheese was produced at the Food Microbiology and Mycotoxicology Laboratory of the Faculty of Animal Science and Food Engineering at the University of São Paulo, Pirassununga campus, from milk produced on the same campus.

The cheese samples (16) were produced in duplicate for each of the following treatments: T1) negative control - cheese only; T2) positive control, cheese with addition of AFM $(0.5 \mu \mathrm{g} / \mathrm{kg})$; T3) cheese with the addition of L. rhamnosus and L. lactis $\left(10^{10}\right.$ cells/g); T4) cheese with the addition of L. rhamnosus, L. lactis and $\mathrm{AFM}_{1}$; T5) cheese with the addition of $S$. cerevisiae (concentration $10^{10}$ cells/g); T6) cheese with the addition of $S$. cerevisiae and $\mathrm{AFM}_{1}$; T7) cheese with the addition of L. rhamnosus, L. lactis and S. cerevisiae; T8) cheese with the addition of L. rhamnosus, L. lactis, S. cerevisiae and AFM. In all treatments, the lactic acid bacteria, S. cerevisiae and AFM were in the same concentration.

The LAB and S. cerevisiae ability to bind $\mathrm{AFM}_{1}$, as well as the interaction between these microorganisms and aflatoxin $\mathrm{M}_{1}$ in the Minas Frescal cheese were evaluated on days 2 and 30 after manufacture.

\subsection{Sample preparation and determination of aflatoxin $M_{1}$}

$\mathrm{AFM}_{1}$ determination in cheese samples was performed as described by Jager et al. (2013). Two grams of $\mathrm{NaCl}, 22 \mathrm{~mL}$ of methanol and $13 \mathrm{~mL}$ of ultrapure water were added to a tube containing $8 \mathrm{~g}$ of the sample. The mixture was centrifuged at $2,078 \mathrm{x}$ g for $15 \mathrm{~min}$., and the obtained supernatant was filtered. $20 \mathrm{~mL}$ of the filtrate was collected in another flask, and $40 \mathrm{~mL}$ of ultrapure water was added. Purification was performed by passing the total volume $(60 \mathrm{~mL})$ through a manifold-coupled immunoaffinity column (Aflatest WB, Vicam ${ }^{\otimes}$ ) at 2-3 drops/sec flow. After this procedure, the column was washed by passing $20 \mathrm{~mL}$ of ultrapure water. Subsequently, the toxin was eluted by passing $1 \mathrm{~mL}$ of HPLC grade methanol. Then, the eluent was evaporated to dryness under a stream of nitrogen at $40^{\circ} \mathrm{C}$ and resuspended with $1 \mathrm{~mL}$ solution of methanol and ultrapure water $(50: 50 \mathrm{v} / \mathrm{v})$.

Final extracts of cheese samples were injected $(20 \mu \mathrm{L})$ into a Shimadzu 10VP liquid chromatograph (Kyoto, Japan), equipped with a 10 AXL fluorescence detector (excitation at $360 \mathrm{~nm}$ and emission above $440 \mathrm{~nm}$ ). A Kinetex $\mathrm{C}_{18}$ column (Phenomenex, Torrance, CA, USA) $4.6 \times 150 \mathrm{~mm}, 2.6 \mu \mathrm{m}$ particle size and an in-line filter of $0.5 \mu \mathrm{m}$ were used. The isocratic mobile phase consisted of methanol/water/acetonitrile (61.4:28.1:10.5, v/v/v) with a flow rate of $0.50 \mathrm{~mL} / \mathrm{min}$. The equipment used in this study included vortex mixer (Fanem, São Paulo, Brazil); centrifuge (SOLAB SL-700, Piracicaba, Brazil); column manifold (Supelco, Bellefonte, Pennsylvania, USA) and vacuum pump (Model 131, type 2V, Primatec, Itu, Brazil).

Calibration curves to detect $\mathrm{AFM}_{1}$ from cheese samples were prepared using standard solution of $\mathrm{AFM}_{1}\left(\right.$ Sigma $\left.^{\oplus}\right)$, diluted in acetonitrile at concentrations of $0.625,1.25,5,10,20 \mu \mathrm{g} / \mathrm{L}$. Integrated peak areas were linearly correlated with the concentrations. The limits of detection (LOD) and quantification (LOQ) were calculated for each method of analysis based on signal:noise ratio of 3:1 and 10:1, respectively. Linearity was evaluated by verifying the coefficient of determination $\left(\mathrm{r}^{2}\right)$ and visual inspection of residual plots of analytical curves. The performance of methods used for determination of $\mathrm{AFM}_{1}$ in cheese samples in the laboratory has been presented elsewhere (Jager et al., 2013), describing limits of detection (LOD) and quantification (LOQ) values of 0.017 and $0.055 \mu \mathrm{g} / \mathrm{kg}$, in cheese samples respectively.

\subsection{Scanning electron microscopy assay}

The cheese samples were prepared for scanning electron microscopy according to proposed by Lobato-Calleros et al. (2002) and Fritzen-Freire et al. (2010) with adaptations. Cylindrical samples of $0.5 \mathrm{~cm}$ diameter by $0.5 \mathrm{~cm}$ height were fixed in $2 \%$ buffer glutaraldehyde (0.1 M phosphate buffer, $\mathrm{pH}$ 7.2) for $6 \mathrm{~h}$. The samples were dehydrated in increasing concentrations of aqueous ethanol solutions $(50 \%, 60 \%, 70 \%, 80 \%, 90 \%$ and $100 \%, 15 \mathrm{~min}$ for 3 times in each, totalizing $45 \mathrm{~min}$ ) and placed in acetone for $1 \mathrm{~h}$. After that, each sample was fractured perpendicular to its long axis and mounted on stubs with fractured face upwards. A scanning electron microscope (Hitachi, TM 3000, Japan) with a high sensibility semiconductor backscattered electron detector was used at $15 \mathrm{kV}$ to observe each sample at a magnification of $1000 \times, 5000 \times$ and $8000 \times$.

\section{Image analysis}

The analysis of the scanning electron microscopy images was performed without the use of a specific software, besides the SEM - Hitachi 3000 device itself, which was used only for image capture. The images were evaluated one by one, being selected according to the following criteria: (1) image sharpness and (2) magnification used, the magnification that presented the sharpest images in all treatments was sought. After choosing the best magnification, which was $5000 \times$, the clearest images and the best images (day 2 and day 30 ) were screened for each treatment through a new screening.

\subsection{Microbiological assay}

Determination of Salmonella sp., Listeria monocytogenes, thermotolerant coliforms and coagulase positive staphylococci in Minas Frescal cheese were performed on days 2 and 30 after 
manufacture following the procedures described by American Public Health Association (2004).

\section{Results and discussion}

Table 1 shows the results of the microbiological analyzes performed on Minas Frescal cheese after 2 and 30 days of storage. Thermotolerant coliforms counts in the samples is in conformity with Brazilian legislation, and all confirmatory tests for Salmonella sp. and Listeria monocytogenes were negative, as were the coagulase tests to verify the positive coagulase staphylococci count (Brasil, 2001). Therefore, it can be said that the use of BAL and S. cerevisiae as a biological method to reduce $\mathrm{AFM}_{1}$ in Minas Frescal cheese had no negative effect on the shelf-life of this cheese, which is generally 21 days. The shelf-life of Minas Frescal cheese is also related to the raw material used, the production process and the initial quantity of microorganism present (Prezzi et al., 2020).

The concentration of $\mathrm{AFM}_{1}$ in cheese from treatments which $\mathrm{AFM}_{1}$ was not included was below the detection limit of the analytical method (Table 2), while the concentration of $\mathrm{AFM}_{1}$ in treatments that included $\mathrm{AFM}_{1}$ ranged from $0.29 \mu \mathrm{g}$ of $\mathrm{AFM}_{1} / \mathrm{kg}$ until undetected.

Table 1. Microbiological analysis of Minas Frescal cheese produced with or without the addition of inactivated cells of lactic acid bacteria and yeast and aflatoxin $M_{1}$ after 2 and 30 days of storage.

\begin{tabular}{|c|c|c|c|c|c|c|c|c|c|c|c|}
\hline Treatment & $\begin{array}{l}\text { Probiotic } \\
\text { culture }^{\mathrm{a}} \\
(\text { cells } / \mathrm{kg})\end{array}$ & $\begin{array}{c}\text { Yeast }^{\mathrm{b}} \\
\text { (cells/kg) }\end{array}$ & $\begin{array}{c}\mathrm{AFM}_{1} \\
\text { in curd } \\
(\mu \mathrm{g} / \mathrm{kg})\end{array}$ & \multicolumn{8}{|c|}{ Microbiological parameters during storage $^{c}$} \\
\hline $\mathrm{T} 1$ & 0 & 0 & 0 & 26 & 273 & $\mathrm{ND}^{1}$ & $\mathrm{ND}^{1}$ & $\mathrm{ND}^{1}$ & $\mathrm{ND}^{1}$ & $<10^{2}$ & $<10^{2}$ \\
\hline $\mathrm{T} 3$ & $2 \times 10^{10}$ & 0 & 0 & 28 & 250 & $\mathrm{ND}^{1}$ & $\mathrm{ND}^{1}$ & $\mathrm{ND}^{1}$ & $\mathrm{ND}^{1}$ & $<10^{2}$ & $<10^{2}$ \\
\hline T7 & $2 \times 10^{10}$ & $10^{10}$ & 0 & 33 & 270 & $\mathrm{ND}^{1}$ & $\mathrm{ND}^{1}$ & $\mathrm{ND}^{1}$ & $\mathrm{ND}^{1}$ & $<10^{2}$ & $<10^{2}$ \\
\hline $\mathrm{T} 2$ & 0 & 0 & 0.5 & 1 & 270 & $\mathrm{ND}^{1}$ & $\mathrm{ND}^{1}$ & $\mathrm{ND}^{1}$ & $\mathrm{ND}^{1}$ & $<10^{2}$ & $<10^{2}$ \\
\hline $\mathrm{T} 4$ & $2 \times 10^{10}$ & 0 & 0.5 & 16 & 19 & $\mathrm{ND}^{1}$ & $\mathrm{ND}^{1}$ & $\mathrm{ND}^{1}$ & $\mathrm{ND}^{1}$ & $<10^{2}$ & $<10^{2}$ \\
\hline T6 & 0 & $10^{10}$ & 0.5 & 42 & 89 & $\mathrm{ND}^{1}$ & $\mathrm{ND}^{1}$ & $\mathrm{ND}^{1}$ & $\mathrm{ND}^{1}$ & $<10^{2}$ & $<10^{2}$ \\
\hline
\end{tabular}

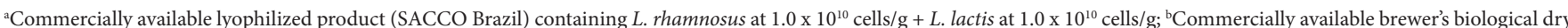

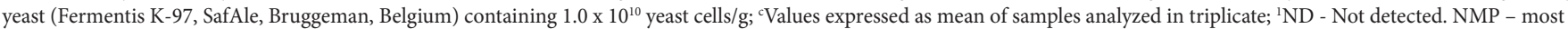

Table 2. Concentrations and percentage reductions of aflatoxin $M_{1}$ in Minas Frescal cheeses manufactured with or without the addition of AFM and heat-killed cells of lactic acid bacteria and yeast during 30 days of storage.

\begin{tabular}{|c|c|c|c|c|c|c|c|}
\hline \multirow{3}{*}{ Treatment } & \multirow{3}{*}{$\begin{array}{l}\text { Probiotic culture } \\
\quad(\text { cells } / \mathbf{k g})\end{array}$} & \multirow{3}{*}{ Yeast $^{\mathrm{f}}($ cells $/ \mathrm{kg})$} & \multirow{3}{*}{$\begin{array}{l}\operatorname{AFM}_{1} \text { in curd } \\
(\mu \mathrm{g} / \mathrm{kg})\end{array}$} & \multicolumn{4}{|c|}{ Aflatoxin $M_{1}$ in cheese during storage } \\
\hline & & & & \multicolumn{2}{|c|}{ Day 2} & \multicolumn{2}{|c|}{ Day 30} \\
\hline & & & & $\begin{array}{c}\text { Concentration } \\
(\mu \mathrm{g} / \mathrm{kg})^{\mathrm{g}}\end{array}$ & $\%$ Reduction $^{\mathrm{h}}$ & $\begin{array}{c}\text { Concentration } \\
(\mu \mathrm{g} / \mathrm{kg})^{\mathrm{g}}\end{array}$ & $\%$ Reduction $^{\mathrm{h}}$ \\
\hline $\mathrm{T} 1$ & 0 & 0 & 0 & $<\mathrm{LOD}$ & - & $<\mathrm{LOD}$ & - \\
\hline $\mathrm{T} 3$ & $2 \times 10^{10}$ & 0 & 0 & $<\mathrm{LOD}$ & - & $<\mathrm{LOD}$ & - \\
\hline $\mathrm{T} 7$ & $2 \times 10^{10}$ & $10^{10}$ & 0 & $<\mathrm{LOD}$ & - & $<\mathrm{LOD}$ & - \\
\hline $\mathrm{T} 2$ & 0 & 0 & 0.5 & $0.29 \pm 0.01$ & $42^{\mathrm{aA}}$ & $0.23 \pm 0.03$ & $54^{\mathrm{aB}}$ \\
\hline $\mathrm{T} 4$ & $2 \times 10^{10}$ & 0 & 0.5 & $0.09 \pm 0.02$ & $82^{\mathrm{bA}}$ & $0.03 \pm 0.01$ & $94^{\mathrm{bB}}$ \\
\hline T6 & 0 & $10^{10}$ & 0.5 & $0.13 \pm 0.02$ & $74^{\mathrm{cA}}$ & $<\mathrm{LOD}$ & $100^{c \mathrm{C}}$ \\
\hline $\mathrm{T} 8$ & $2 \times 10^{10}$ & $10^{10}$ & 0.5 & $0.13 \pm 0.01$ & $74^{\mathrm{cA}}$ & $<\mathrm{LOD}$ & $100^{\mathrm{cB}}$ \\
\hline
\end{tabular}

${ }^{\mathrm{a}-\mathrm{d}}$ In the same column, means followed by different letters differ significantly $(P<0.05) ;{ }^{\mathrm{A}-\mathrm{C}}$ In the same line, means followed by different letters differ significantly $(P<0.05) ;{ }^{\mathrm{C}} \mathrm{Commercially}$ available lyophilized product (SACCO Brazil) containing L. rhamnosus at $1.0 \times 10^{10}$ cells/g + L. lactis at $1.0 \times 10^{10}$ cells/g; ${ }^{\mathrm{f}}$ Commercially available brewer's biological dry yeast (Fermentis

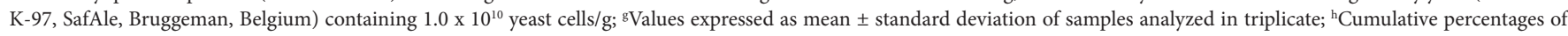
reductions related to the concentration of aflatoxin $\mathrm{M}_{1}$ added in cheese curd during processing. LOD: Limit of detection $(0.017 \mu \mathrm{g} / \mathrm{kg})$. 
In the present study, the scanning electron microscopy assay was useful to support the results obtained through the analysis by HPLC, showing that there is a connection or interaction between the surfaces of $L A B$, yeast and aflatoxin $M_{1}$, separately and in associated treatment. In addition, it was possible to observe few changes in (1) LAB and S. cerevisiae when aflatoxin was attached and (2) in the microstructure of Minas Frescal cheese with aflatoxin and $\mathrm{LAB}$ and/or $S$. cerevisiae added versus cheese containing only these microorganisms.

Figures 1 to 3 show the micrographs of the different treatments applied to Minas Frescal cheese evaluated in this work, after days 2 and 30 of storage. Differences were observed in the microstructure of the cheese and in the morphology of the microorganisms used to reduce $\mathrm{AFM}_{1}$.

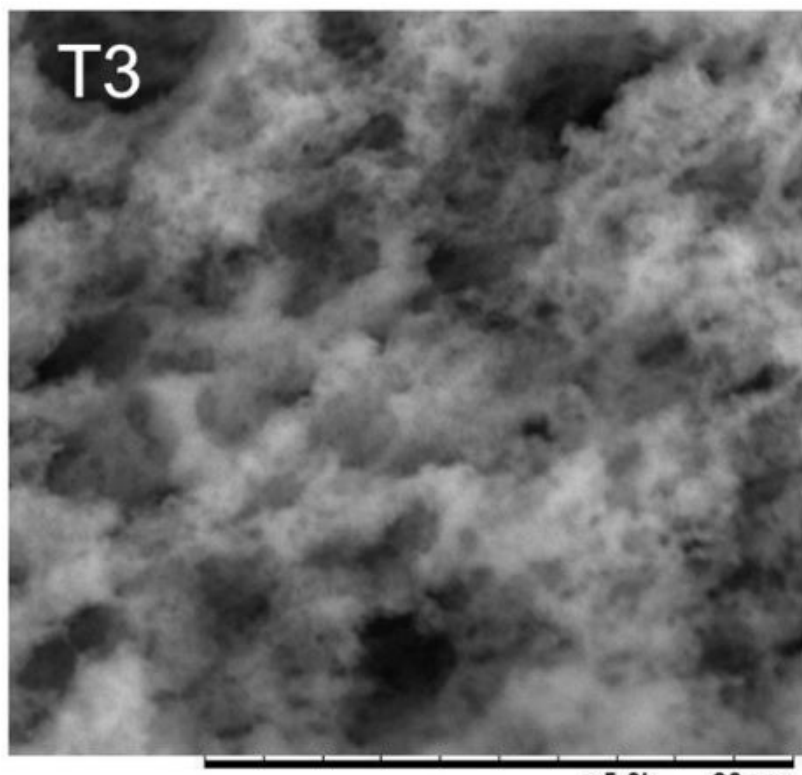

$\times 5.0 \mathrm{k} \quad 20 \mathrm{um}$

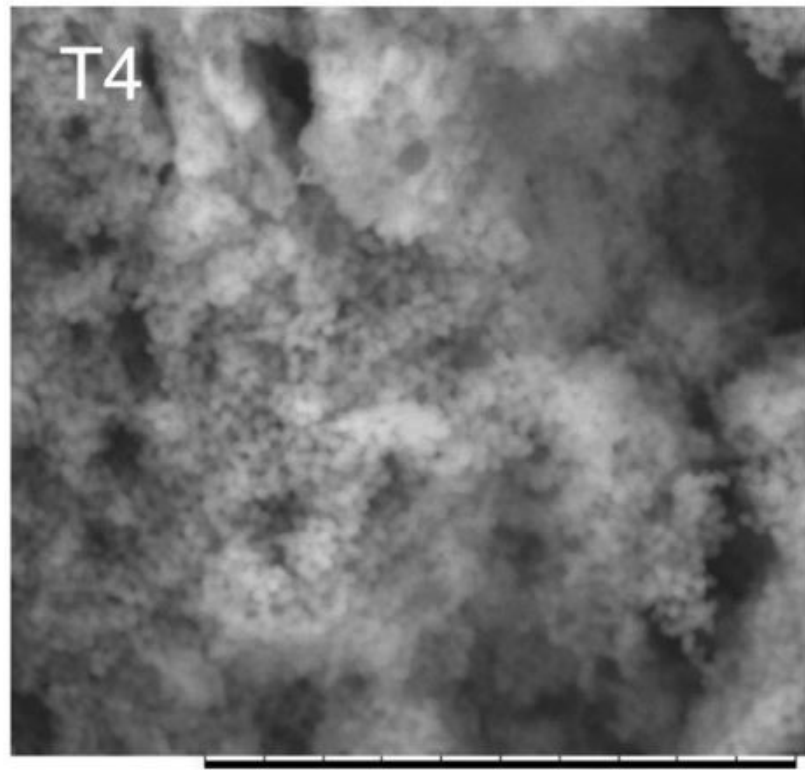

$\times 5.0 \mathrm{k} \quad 20 \mathrm{um}$
The cheese microstructure is a spatial arrangement of casein micelles that join in groups and chains to form a viscoelastic protein network through which moisture, fat globules, miners and bacteria are dispersed (Aldalur et al., 2019).

Differences were observed in the microstructure of the cheese and in the structure of the lactic acid bacteria (Figure 1). Comparing the images of treatments 3 and 4 on days 2 and 30 (T3 and T3.1 and T4 and T4.1, respectively) it is possible to observe that the cheese matrix it has a more compact structure on day 2 of both treatments, and it is not possible to even visualize the lactic acid bacteria. After 30 days of production, the cheese network is less compacted, and it is possible to observe lactic acid bacteria in treatment 3 (T3.1) and in treatment 4 (T4.1), it is possible to observe $\mathrm{AFM}_{1}$ (white dots) linked to lactic acid bacteria.
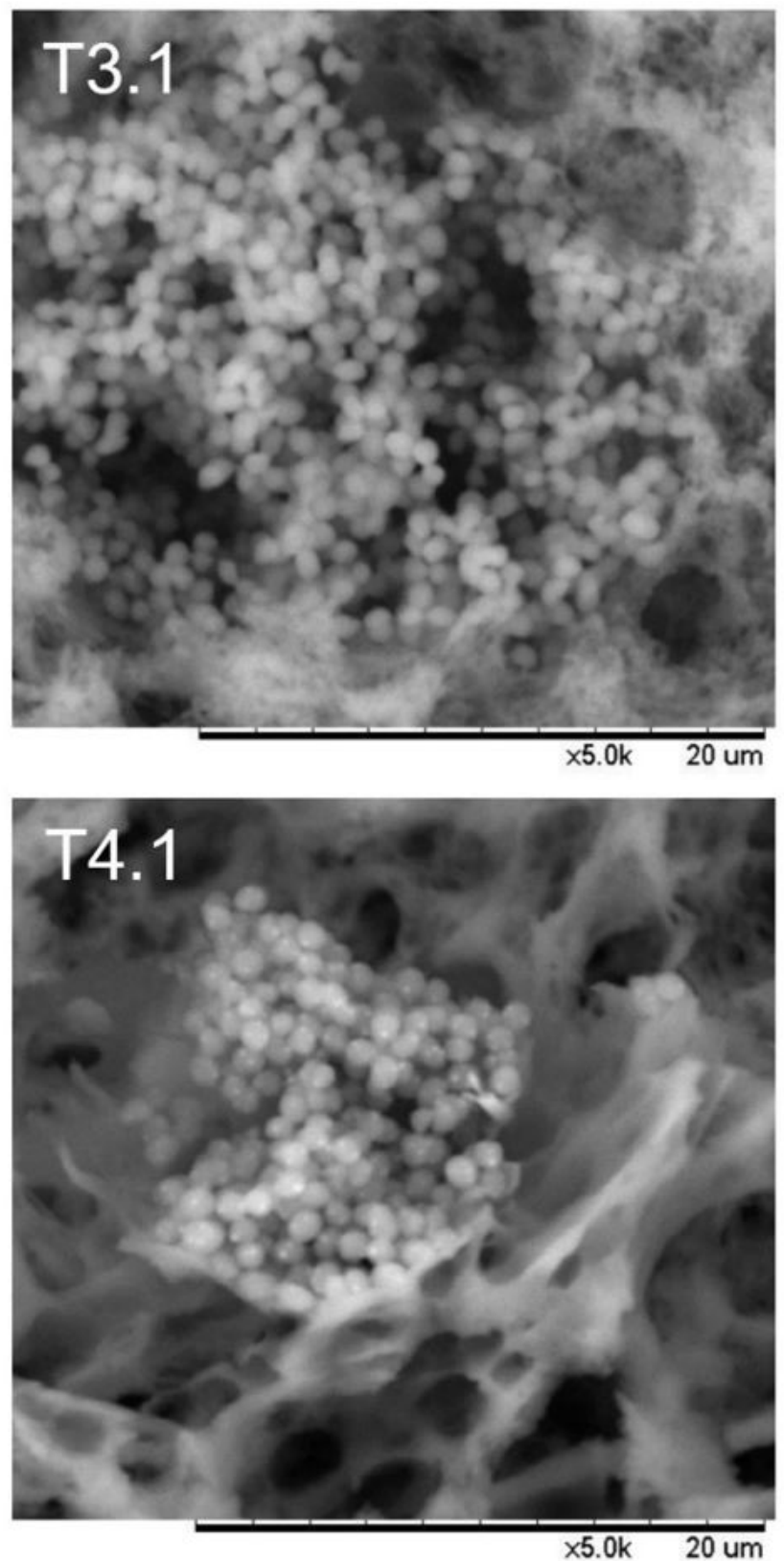

Figure 1. Scanning electron microscopy images of treatments 3 and 4 on days 2 and 30 after manufactured. 
Fritzen-Freire et al. (2010) and Madadlou et al. (2007) reported that during cheese storage, structural changes may occur due to moisture loss and biochemical changes, as well as due to changes in cheese properties. In addition, another factor that can contribute to the formation or changes in the microstructure of the cheese is the use of lactic acid bacteria, due to their ability to improve the body and texture of the cheese (Centeno et al., 2002; Merrill et al., 1996). Also, Abdelmotilib et al. (2018) observed that strains of Lactobacillus plantarum, Lactobacillus acidophilus and Bifidobacterium bifidum when in contact with $\mathrm{AFM}_{1}$ had spots on the cell wall after adsorption of the toxin.

The effects of the microorganisms used to reduce $\mathrm{AFM}_{1}$ can be observed in the LAB treatment (T4), supported by the SEM images. Analyzes by HPLC showed that LAB has a high capacity to reduce $\mathrm{AFM}_{1}$. On day 2, a reduction of $82 \%$ was observed (Table 2), followed by an increase in the percentage of reduction on day 30 , reaching $94 \%$.

In Figure 2 its possible comparing the images of treatments 5 and 6 (T5, T5.1, T6 and T6.1 on days 2 and 30, respectively). Differences were observed in the cheese matrix between days 2 and 30, both between T5, T5.1 and between T6 and T6.1, in both cases there was an increase in the pores of the network. Both in T6 and T6.1 it is possible to observe AFM binding to the wall of S. cerevisiae, which, when the toxin is bound, changes its shape, becoming elongated or oval.

In agreement with our study, Hamad et al. (2017) reported that SEM analysis showed that the microorganism's surface is able to adsorb the toxin particles that appear as a small dot on the microorganism's cell walls. Abdelmotilib et al. (2018) reported in their study that non-viable strains of the yeasts
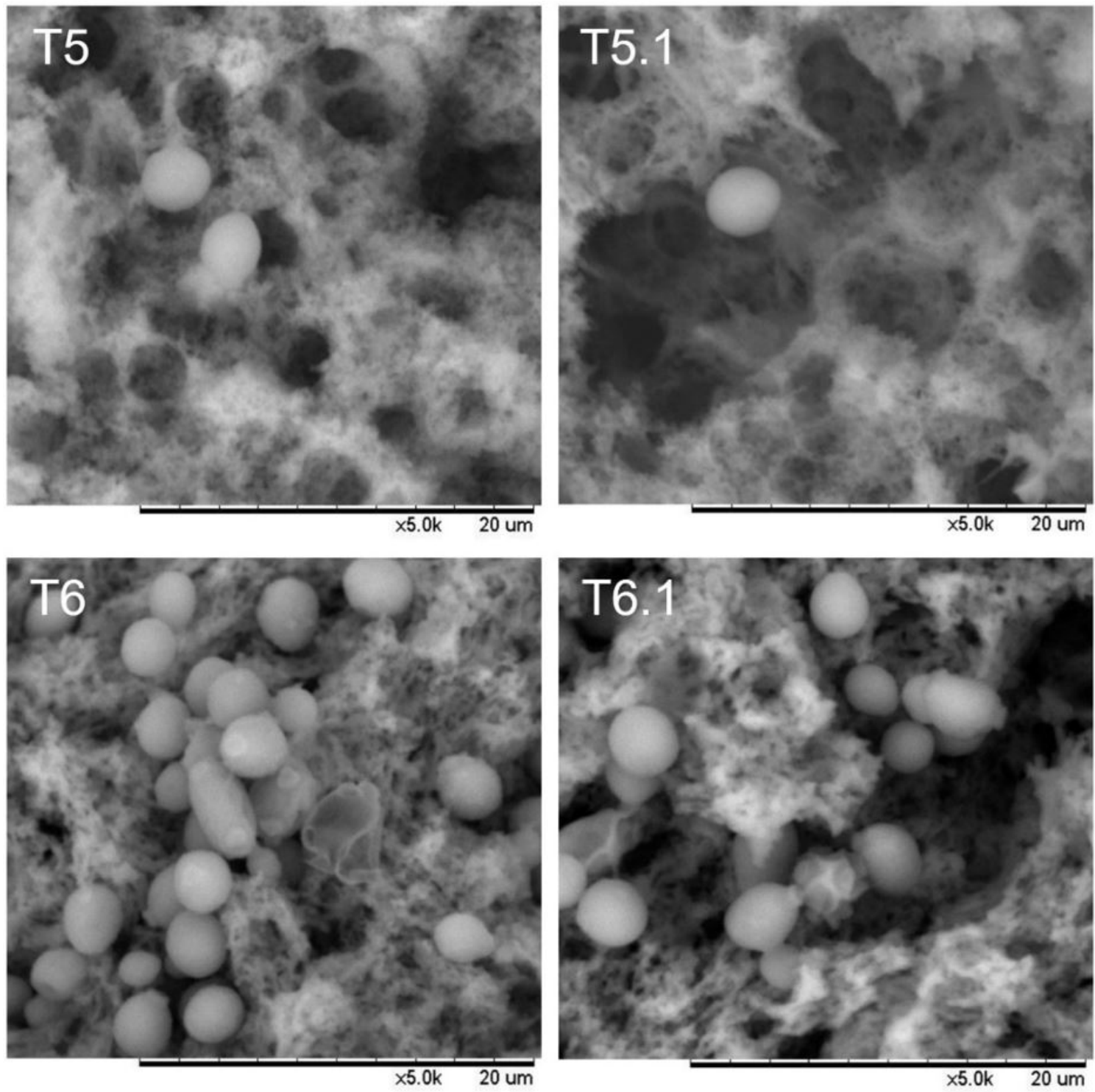

Figure 2. Scanning electron microscopy images of treatments 5 and 6 on days 2 and 30 after manufactured. 
Kluyveromyces lactis and S. cerevisiae showed changes in the cell wall after adsorption of AFM.

Supporting SEM images, HPLC analyzes showed S. cerevisiae, as a microorganism choice to reduce $\mathrm{AFM}_{1}$, once it presented a lower percentage of reduction than LAB initially, $74 \%$, however, after 30 days it was more efficient, reaching a percentage reduction of $\mathrm{AFM}_{1}$ of $100 \%$.

Treatments 7 and 8 (T7, T7.1, T8 and T8.1 on days 2 and 30, respectively) are in Figure 3. Differences in the cheese matrix between treatments without $\mathrm{AFM}_{1}$ (T7 and T7.1) and with $\mathrm{AFM}_{1}$ (T8 and T8.1) and in the same treatment were observed between days, day 2 (T7 and T8) and day 30 (T7.1 and T8.1). When comparing T7 and T7.1 to T8 and T8.1, it is possible to observe that the first presents a cheese matrix with a more compact structure than the other. According to Fox et al. (2017) a less compacted microstructure may be the result of demineralization (loss of calcium and phosphate in the casein micelle) that occurs due to the decrease in $\mathrm{pH}$. A fact that may have occurred with Minas Frescal cheese over the course of thirty days, there may have been a decrease in $\mathrm{pH}$ due to the increase in lactic acid. Fritzen-Freire et al. (2010) reported that after 28 days, the Minas Frescal cheese with a higher lactic acid content showed a less compacted structure and less deformations.

Regarding $\mathrm{AFM}_{1}$ binding to the yeast, when comparing T7 and T7.1 with T8 and T8.1 in Figure 3, it is possible to observe the stains on the cell wall of S. cerevisiae in T8 and T8.1. These spots indicate that $\mathrm{AFM}_{1}$ is adsorbed to the yeast cell wall. In agreement with our study, Abdelmotilib et al. (2018) and Hamad et al. (2017) reported that the surface of the microorganism is able to adsorb AFM particles that appear as small dots or spots on the cell wall of microorganisms. Supporting SEM images, the result
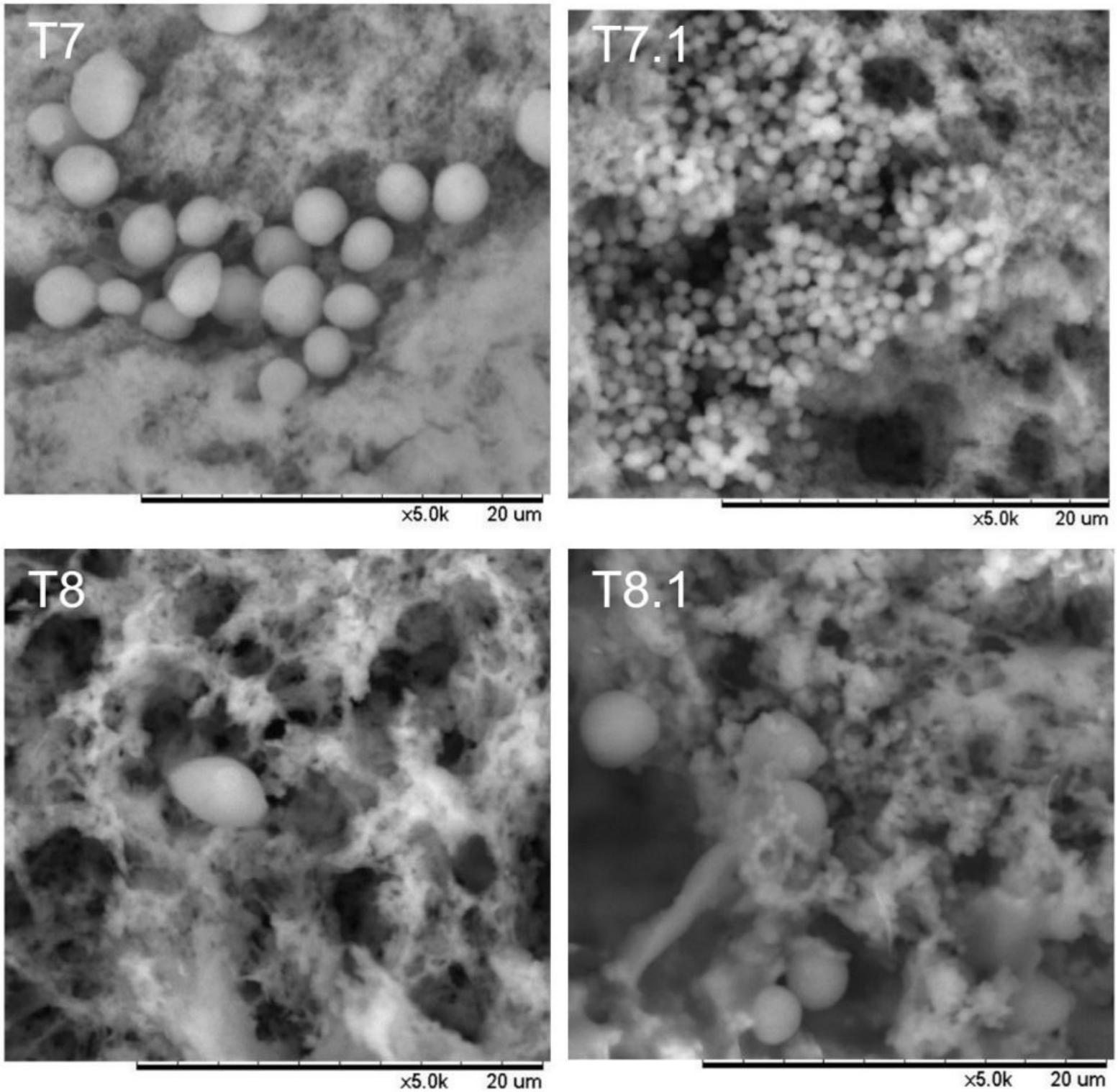

Figure 3. Scanning electron microscopy images of treatments 7 and 8 on days 2 and 30 after manufactured. 
obtained through HPLC showed that on day 2, the treatment that received $\mathrm{LAB}$ and $S$. cerevisiae combined showed the same percentages of reduction as the treatment that received only $S$. cerevisiae. On day 2, a reduction of $\mathrm{AFM}_{1}$ of $74 \%$ was observed and on day $30,100 \%$.

\section{Conclusions}

The use of microorganisms as a biological method to reduce $\mathrm{AFM}_{1}$ is efficient in Minas Frescal cheese and does not affect the microbiological parameters of the product. The reduction in $\mathrm{AFM}_{1}$ varied according to the microorganism used in the treatments. Saccharomyces cerevisiae showed greater capacity to bind $\mathrm{AFM}_{1}$ over time, compared to LABs. Scanning electron microscopy was especially useful, confirming that both lactic acid bacteria and S. cerevisiae were able to bind $\mathrm{AFM}_{1}$ particles in Minas Frescal cheese. In addition, it allowed visualizing the changes that occurred in the cheese protein matrix over time and according to the different treatments.

\section{Acknowledgements}

The authors would like to thanks: São Paulo Research of Foundation, FAPESP [Grants \#2017/20081-6 and \#2017/196831], Brazilian National Council for Scientific and Technological Development, CNPq [Grant \#302195/2018-1], and this study was financed in part by the Coordenação de Aperfeiçoamento Pessoal de Nível Superior - Brasil (CAPES) - Finance Code 001.

\section{References}

Abdelmotilib, N., Hamad, G., Elderea, H., Salem, E., \& Sohaimy, S. (2018). Aflatoxin $M_{1}$ reduction in milk by a novel combination of probiotic bacterial and yeast strains. European Journal of Nutrition \& Food Safety, 8(2), 83-99. http://dx.doi.org/10.9734/ EJNFS/2018/39486.

Ahmadi, E. (2020). Potential public health risk due to consumption of contaminated bovine milk with aflatoxin $\mathrm{M}_{1}$ and Coxiella burnetii in the West of Iran. International Journal of Dairy Technology, 73(3), 479-485. http://dx.doi.org/10.1111/1471-0307.12687.

Aldalur, A., Ong, L., Bustamante, M. Á., Gras, S. L., \& Barron, L. J. R. (2019). Impact of processing condictions on microstructure, texture and chemical properties of model cheese from sheep milk. Food and Bioproducts Processing, 116, 160-169. http://dx.doi.org/10.1016/j. fbp.2019.05.003.

American Public Health Association - APHA. (2004). Standard methods for the examination of dairy products (17th ed.). Washington: APHA.

Assaf, J. C., Khoury, A. E., Chokr, A., Louka, N., \& Atoui, A. (2019). A novel method for elimination of aflatoxin $\mathrm{M}_{1}$ in milk using Lactobacillus rhamnosus GG biofilm. International Journal of Dairy Technology, 72(2), 248-256. http://dx.doi.org/10.1111/1471-0307.12578.

Barukčić, I., Bilandžić, N., Markov, K., Jakopović, K. L., \& Božanić, R. (2018). Reduction in aflatoxin $M_{1}$ concentration during production and storage of selected fermented milks. International Journal of Dairy Technology, 71(3), 734-740. http://dx.doi.org/10.1111/14710307.12490 .

Bodbodak, S., Hesari, J., Peighambardoust, S. H., \& Mahkam, M. (2018). Selective decontamination of aflatoxin $M_{1}$ in milk by molecularly imprinted polymer coated on the surface of stainless steel plate.
International Journal of Dairy Technology, 71(4), 868-878. http:// dx.doi.org/10.1111/1471-0307.12551.

Brasil, Agência Nacional de Vigilância Sanitária. (2001, January 10). Regulamento técnico sobre padrões microbiológicos para alimentos (Resolução RDC nº 12, de 2 de janeiro de 2001). Diário Oficial [da] República Federativa do Brasil.

Cagri-Mehmetoglu, A. (2018). Food safety challenges associated with traditional foods of Turkey. Food Science and Technology, 38(1), 1-12. http://dx.doi.org/10.1590/1678-457x.36916.

Campagnollo, F. B., Khaneghah, A. M., Borges, L. L., Bonato, M. A., Fakhri, Y., Barbalho, C. B., Barbalho, R. L. C., Corassin, C. H., \& Oliveira, C. A. F. (2020). In vitro and in vivo capacity of yeast-based products to bind to afatoxins $B_{1}$ and $M_{1}$ in media and foodstuffs: a systematic review and meta-analysis. Food Research International, 137, 1-55. http://dx.doi.org/10.1016/j.foodres.2020.109505.

Centeno, J. A., Tomillo, F. J., Fernández-García, E., Gaya, P., \& Nuñez, M. (2002). Effect of wild strains of Lactococcus lactis on the volatile profile and the sensory characteristics of ewes' raw milk cheese. Journal of Dairy Science, 85(12), 3164-3172. http://dx.doi.org/10.3168/jds. S0022-0302(02)74404-4. PMid:12512589.

Corassin, C. H., Bovo, F., Rosim, R. E., \& Oliveira, C. A. F. (2013). Efficiency of Saccharomyces cerevisiae and lactic acid bacteria strains to bind aflatoxin $\mathrm{M}_{1}$ in UHT skim milk. Food Control, 31(1), 80-83. http://dx.doi.org/10.1016/j.foodcont.2012.09.033.

Fernandes, A. M., Corrêa, B., Rosim, R. E., Kobashigawa, E., \& Oliveira, C. A. F. (2012). Distribution and stability of aflatoxin $M_{1}$ during processing and storage of Minas Frescal cheese. Food Control, 24(1-2), 104-108. http://dx.doi.org/10.1016/j.foodcont.2011.09.010.

Fox, P., Guinee, T., Cogan, T., \& McSweeney, P. L. (2017). Fundamentals of cheese science (2nd ed.). Boston: Springer. http://dx.doi. org/10.1007/978-1-4899-7681-9.

Fritzen-Freire, C. B., Müller, C. M. O., Laurindo, J. B., \& Prudêncio, E. S. (2010). The influence of Bifidobacterium Bb-12 and lactic acid incorporation on the properties of Minas Frescal cheese. Journal of Food Engineering, 96(4), 621-627. http://dx.doi.org/10.1016/j. jfoodeng.2009.09.010.

Gonçalves, B. L., Corassin, C. H., \& Oliveira, C. A. F. (2015a). Mycotoxicoses in dairy cattle: a review. Asian Journal of Animal and Veterinary Advances, 10(11), 752-760. http://dx.doi.org/10.3923/ ajava.2015.752.760.

Gonçalves, B. L., Muaz, K., Coppa, C. F. S. C., Rosim, R. E., Kamimura, E. S., Oliveira, C. A. F., \& Corassin, C. H. (2020). Aflatoxin $M_{1}$ absorption by non-viable cells of lactic acid bacteria and Saccharomyces cerevisiae strains in Frescal cheese. Food Research International, 136, 109604. http://dx.doi.org/10.1016/j.foodres.2020.109604. PMid:32846626.

Gonçalves, B. L., Rosim, R. E., de Oliveira, C. A. F., \& Corassin, C. H. (2015b). The in vitro ability of different Saccharomyces cerevisiae: based products to bind aflatoxin $B_{1}$. Food Control, 47, 298-300. http://dx.doi.org/10.1016/j.foodcont.2014.07.024.

Hajmohammadi, M., Valizadeh, R., Naserian, A., Nourozi, M. E., Rocha, R. S., \& Oliveira, C. A. F. (2020). Composition and occurrence of aflatoxin $\mathrm{M}_{1}$ in cow's milk samples from Razavi Khorasan Province, Iran. International Journal of Dairy Technology, 73(1), 40-45. http://dx.doi.org/10.1111/1471-0307.12661.

Hamad, G. M., Zahran, E., \& Hafez, E. E. (2017). The efficacy of bacterial and yeasts strains and their combination to bind aflatoxin $B_{1}$ and $\mathrm{B}_{2}$ in artificially contaminated infants food. Journal of Food Safety, 37(4), 1-9. http://dx.doi.org/10.1111/jfs.12365. 
Jager, A. V., Tedesco, M. P., Souto, P. C. M. C., \& Oliveira, C. A. F. (2013). Assessment of aflatoxin intake in São Paulo, Brazil. Food Control, 33(1), 87-92. http://dx.doi.org/10.1016/j.foodcont.2013.02.016.

Lee, C. S., Hyun, Y., \& Choi, J. Y. (2019). Syntesis and electrochemical performance of transition metal coated carbon nanofibers on $\mathrm{Ni}$ foan as anode materials for lethium secondary batteries. In S. Yaragalla, R. Mishra \& H. J. Maria (Eds.), Carbon based nanofillers and their rubber nanocomposites (pp. 225-242). Amsterdam: Elsevier. http://dx.doi.org/10.1016/B978-0-12-813248-7.00007-9.

Lobato-Calleros, C., Ramírez-Santiago, C., Osorio-Santiago, V., Vernon-Carter, E. J., \& Hornelas-Uribe, Y. (2002). Microstructure and texture of Manchego chesselike products made with canola oil, lipophilic and hidrophilic emulsifiers. Journal of Texture Studies, 33(3), 165-182. http://dx.doi.org/10.1111/j.1745-4603.2002.tb01343.x.

Ma, Z. X., Amaro, F. X., Romero, J. J., Pereira, O. G., Jeong, K. C., \& Adesogan, A. T. (2017). The capacity of silage inoculant bacteria to bind aflatoxin $\mathrm{B}_{1}$ in vitro and artificially contaminated corn silage. Journal of Dairy Science, 100(9), 7198-7210. http://dx.doi. org/10.3168/jds.2016-12370. PMid:28711253.

Madadlou, A., Khosrowshahi asl, A., Mousavi, M. E., \& Farmani, J. (2007). The influence of brine concentration on chemical composition and texture of Iranian White cheese. Journal of Food Engineering, 81(2), 330-335. http://dx.doi.org/10.1016/j.jfoodeng.2006.11.010.

Martey, E., Etwire, P. M., \& Denwar, N. (2020). Improved estorage technique and management of aflatoxin in peanut production: evidence from Ghana. Scientific American, 8, 1-14. http://dx.doi. org/10.1016/j.sciaf.2020.e00381.

Merrill, R. K., Oberg, C. J., McManus, W. R., Kalab, M., \& McMahon, D. J. (1996). Microstructure and physical properties of a reduced fat
Mozzarella cheese made using Lactobacillus casei ssp. casei adjunct culture. Lebensmittel-Wissenschaft + Technologie, 29(8), 721-728. http://dx.doi.org/10.1006/fstl.1996.0112.

Min, L., Li, D., Tong, X., Sun, H., Chen, W., Wang, G., Zheng, N., \& Wang, J. (2020). The challenges of global occurence of aflatoxin $M_{1}$ contamination and the reduction of aflatoxin $\mathrm{M}_{1}$ in milk over the past decade. Food Control, 117, 1-10. http://dx.doi.org/10.1016/j. foodcont.2020.107352.

Öztürk Yilmaz, S., \& Altinci, A. (2019). Incidence of aflatoxin $M_{1}$ contamination in milk, white cheese, kashar and butter from Sakarya, Turkey. Food Science and Technology, 39(Suppl. 1), 190194. http://dx.doi.org/10.1590/fst.40817.

Park, N. Y., Cho, Y. H., Choi, K., Lee, E. H., Kim, Y. J., Kim, J. H., \& Kho, Y. (2019). Parabens in breast milk and possible sources of exposure among lactating women in Korea. Environmental Pollution, 255(Pt 2), 1-8. http://dx.doi.org/10.1016/j.envpol.2019.113142. PMid:31563777.

Park, S., Lee, J.-Y., You, S., Song, G., \& Lim, W. (2020). Neurotoxic effects of aflatoxin $B_{1}$ on human astrocytes in vitro ando $n$ glial cell development in Zebrafish in vivo. Journal of Hazardous Materials, 386, 1-39. http://dx.doi.org/10.1016/j.jhazmat.2019.121639. PMid:31787402.

Prezzi, L. E., Lee, S. H. I., Nunes, V. M. R., Corassin, C. H., Pimentel, T. C., Rocha, R. S., Ramos, G. L. P. A., Guimarães, J. T., Balthazar, C. F., Duarte, M. C. K. H., Freitas, M. Q., Esmerino, E. A., Silva, M. C., Cruz, A. G., \& Oliveira, C. A. F. (2020). Effect of Lactobacillus rhamnosus on growth of Listeria monocytogenes and Staphylococcus aureus in probiotic Minas Frescal cheese. Food Microbiology, 92, 103557. http://dx.doi.org/10.1016/j. fm.2020.103557. PMid:32950151. 